\title{
Pelatihan wirausaha pengolahan rumput laut
}

\author{
Amal Aqmal ${ }^{1}$, Fatmawati Fatmawati ${ }^{2}$, Nur Hadijah Yunianti ${ }^{3}$ \\ ${ }^{1,2}$ Fa kultas Pertanian, Universitas Bosowa Makassar \\ ${ }^{3}$ Fakultas Teknik, Universitas Bosowa Makassar
}

\begin{abstract}
The Partners of the Community Partnership Program(PKM) are seaweed farmer grou ps, namely the partner group (1) Malelaya, its leader Sampara, and the partnergroup(2)Bina Mandiri, chaire d by Daeng Ny au, who has a desire to develop a seaweed processing business in the la wi la wi becomes a new product, so it ca $\mathrm{n}$ be a $\mathrm{n}$ alternative business. The problem of partners is not having the knowledge and skills in sea weed processing that can be marketed in the form of fast food. Another problem is that the type of seaweed jens la wi-selling is very low and ea sily da maged, so that it requires another alternative to be used a s additional income in the family in particular. The implementation methods a re: lectures, demonstrations, discussions, questions and answe rs, and a ssistance. The results a chieved are (1) Partners have knowledge in sea weed processing. (2) The partner has knowledge and skills in processing pestle pestle pestle. (3) Partners have skills in making seaweed meatballs. (4)Mitra has various types of sea weed meatballs entrepreneurialspirit.
\end{abstract}

Key words: seaweed farmers, meatballs, fish fillets

\section{PENDAHULUAN}

Mitra (PKM) adalah kelompok petani rumput laut, di Desa Punaga Kabupaten Takalar. PKM1 kelompok malelaya ketuanya Sampara, dan PKM2 kelompok Bina Mandiri yang diketua oleh Daeng Nyau.

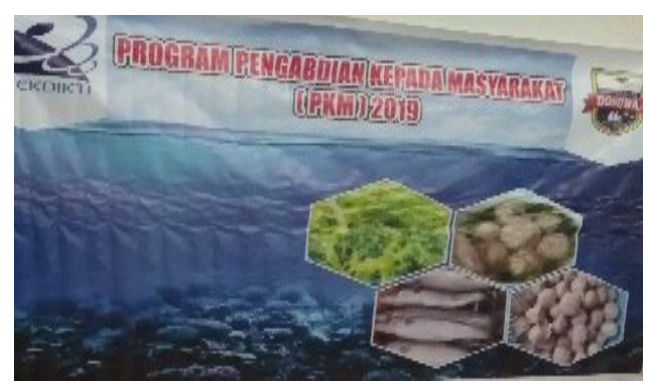

Gambar 1. Spanduk Kegiatan PKM

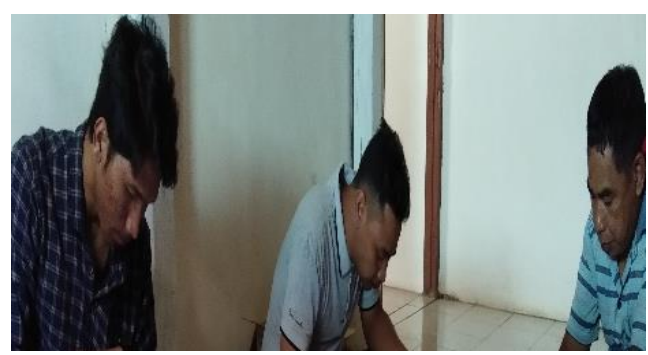

Gambar 2. Mitra PKM

Mitra program kemitraan masyarakat mengalami permasalahan pengolahan rumput laut jenis lawi-lawi. Rumput laut jenis ini nilai jualnya sangat murah, dan mudah mengalami kerusakan namun pemeliharaannya sangat mudah. Olehnya itu dapat diolah menjadi bakso yang dipadukan dengan ikan menjadi bakso rumput laut.

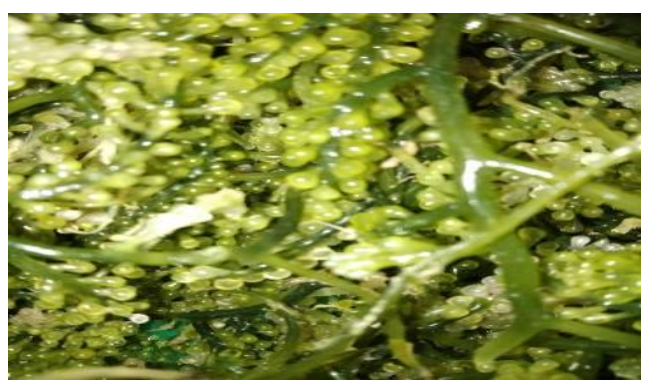

Gambar 3. Rumput laut lawi-lawi

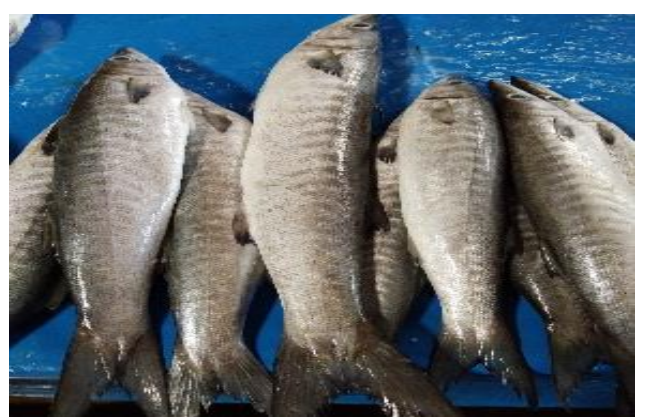

Gambar 4. Ikan alu-alu

Permasalahan yang diperioritaskan oleh mitra sesusuai dengan hasil pertemuan yaitu kurangnya 
pengetahuan tentang manajemen usaha atau berwirausaha dalam pengolahan rumput laut menjadi prodak jadi atau siap untuk dikonsumsi atau dipasarkan kepada konsumen, dan tidak memiliki keterampilan dalam pengolahan rumput laut segar jenis lawi-lawi menjadi produk bakso yang dipadukan dengan ikan surimi, sehingga dapat memberikan nilai tambah dan nilai iptek dari hasil panen rumput laut yang dipadukan dengan surimi.

\section{METODE PELAKSANAAN}

Metode pelaksanaan kegiatan di Desa Punaga Kecamatan Mangarabombang Kabupaten Takalar yang menjadi lokasi Program Kemitraan Masyarakat (PKM), dimana masyarakatnya mayoritas mata pencahariannya adalah petani rumput laut, adapun metode yang digunakan yaitu melalui pendekatan dalam penyelesaian permasalahan mitra adalah "model participatory rapid appracial dan transformasi technology". Kedua metode pendekatan ini dilakukan untuk meningkatkan partisipsi masyarakat atau mitra baik dalam perumusan masalah maupun penyelesaian-nya, demi memudahkan pelaksanaan kegiatan untuk melakukan perubahan pola pikir mitra khususnya dalam mentransfer teknologi tepat guna.

Dengan adanya pendekatan partisipasi mitra di lokasi memberikan respon yang cukup aktif, selanjutnya, kedua pendekatan ini dilakukan, maka kegiatan kerja berikutnya adalah memberikan pemahaman dan penjelasan tentang cara pengolahan secara efektif dan efisien melalui pelatihan dan ceramah dilanjutkan dengan pendampingan. Sistematika Kegiatan yang telah dilakukan (1) Melakukan penyuluhan dan pelatihan, (2) Melakukan pendampingan mitra. Partisipasi mitra terhadap pelaksanaan program, berdasarkan hasil pelaksanaan telah memperlihatkan sikap aktif mitra program. Ditandai dengan adanya kesediaan menyiapkan tempat dan meluangkan waktunya untuk menghadiri penyuluhan dan pelatihan tentang pengeloaan pasca panen rumput laut.

Metode pendekatan yang telah dilaksanakan adalah metode penyuluhan dan pelatihan, dalam penerapan teknologi tepat guna pada pengolahan rumput laut menjadi bakso ikan rumput laut, guna meningkatkan nilai jual sehingga dapat menambah pendapatan mitra. Bakso ikan rumput laut terbuat dari daging ikan yang berwarna putih pada kegiatan ini menggunakan ikan alu-alu atau ikan bara kuda yang dihancurkan atau disebut surimi, dan rumput laut dilakukan pencucian. Untuk lebih jelasnya bagaimana pengolahan bakso ikan rumput laut adalah sebagai berikut.

\section{A. Reparasi Rumput Laut Segar}

1. Pembersihan rumput laut segar yaitu: sortir, pencucian sampai bersih bersih dengan air mengalir atau air bersih minimal tiga kali pencucian.

2. Perendaman rumput laut dilakukan dengan menggunakan air panas untuk menghilangkan warna dari rumput laut, dan dapat melunakkan teksturnya.

3. Rumput laut kemudian di potong-potong, untuk penghancuran.

4. Penghancuran rumput laut dengan diblender hingga menjadi bubur rumput.

\section{B. Pembuatan Fillet Ikan}

1. Pembuatan fillet ikan alu-alu segar yaitu penyiangan dengan cara membuang kepala dan jeroan, kemudian pencucian hingga bersih.

2. Ikan telah di bersihkan kemudian disayat secara memanjang pada bagian punggung, pengambilan daging ikan dengan cara mengeruk dengan menggunakan sendok tanpa tulang.

3. Daging ikan fillet yang telah bersih tersebut diblender menggunakan air es sehingga menghasilkan surimi atau ikan lumat.

\section{Persiapan Bumbu}

Bumbu berupa garam beryodium, bawang putih, bawang goreng merah, lada bubuk, gula putih, penggunaan penyedap monosodium glutamate atau vetsin atau menggunakan penyedap merek lain sesuai selera. Boleh juga tanpa penambahan penyedap, cukup menggunakan garam saja dan gula putih. 


\section{Pembuatan Bakso}

Pengolahan bakso sangat berpengaruh pada kualitas bahan baku, dalam hal ini mutu rumput laut dan surimi ikan yang dipergunakan yang akan dihasilkan (Daniati, 2005). Pengolahan bakso ikan sebagai berikut:

1. Rumput laut yang telah diblender dengan konsentrasi 30\%, masukan ketempat pencampuran adonan.

2. Penambahan surimi atau ikan lumat dengan konsentrasi $25 \%$.

3. Pencampuran bahan tambahan berupa bawang merah goreng $3 \%$, bawang putih $5 \%$, yang telah dihaluskan, lada bubuk $1 \%$, garam $5 \%$, es batui $1 \%$ dalam adonan yang sedang digiling agar temperaturnya tetap

4. Selama pencampuran dimasukan sedikit demi sedikit tepung sebanyak 30\% sampai adonan menjadi kalis, yang terdiri dari tepung tapioka, tepung jagung, tepung bumbu rasa bakso.

5. Proses pembuatan bakso dengan menggunakan cetakan.

6. Pemasakan bakso dengan air hangat pada suhu $\pm(40-70)^{\circ} \mathrm{C}$ hingga bakso terapung selama kurang lebih 3 menit.

7. Pemasakan bakso dilanjutkan dengan uap air dalam dandang hingga baksonya menjadi matang.

8. Setelah matang dinginkan selama \pm 5 menit sebaiknya dalam air es.

9. Bakso siap disajikan kepada konsumen, atau bakso setelah dingin dilanjutkan dengan pengemasan, pelabelan, dan pemasaran.

Pengolahan bakso rumput laut secara praktis dapat dilihat pada Gambar 5.

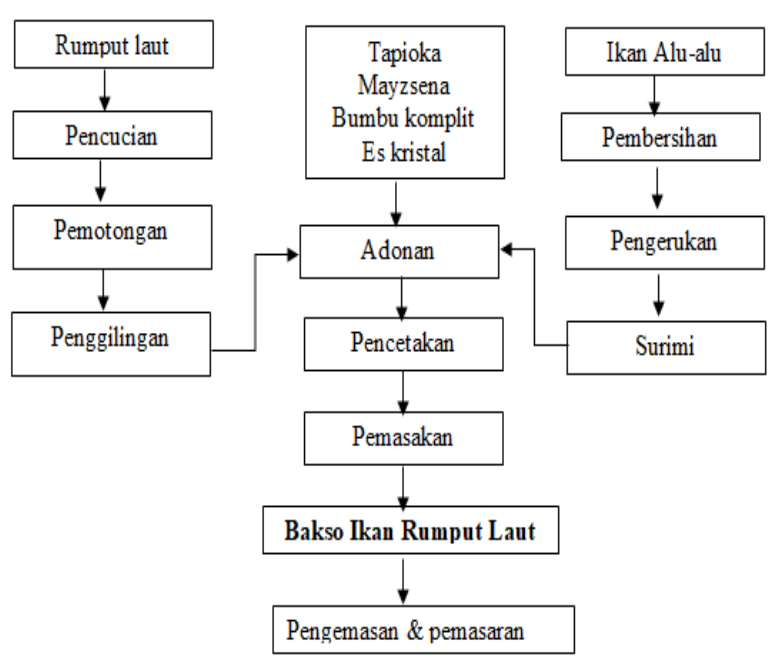

Gambar 5. Skema pengolahan bakso ikan rumput laut

\section{HASIL DAN PEMBAHASAN}

\section{A. Bidang Produksi}

Pada awalnya proses produksi pasca panen rumput laut dari petani selaku mitra program masih menganut model panen dan penjemuran selanjutnya langsung menjual secara gelondongan tanpa adanya pemberian perlakuan walaupun tingkat harga sangat rendah seperti Rp $4000-5000 / \mathrm{kg}$. Adanya program kemitraan masyarakat dari Dirjen Dikti, maka cara yang sangat sederhana, kini mitra sudah memahami dan mengetahui pengelolaan pasca panen rumput laut yang lebih inovatif. Inovatif yaitu pengolahan rumput laut segar menjadi produk yang siap untuk dikonsumsi atau dipasarkan. Selanjutnya tahap pembersihan rumput laut. Adapun tahap produksi dapat dilihat pada Gambar 6 dan 7.

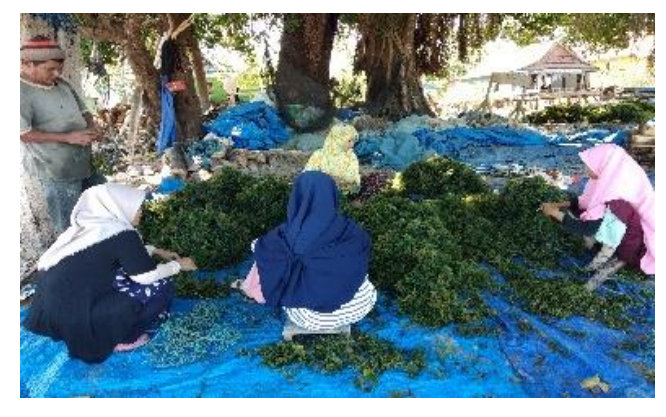

Gambar 6. Hasil panen rumput laut 


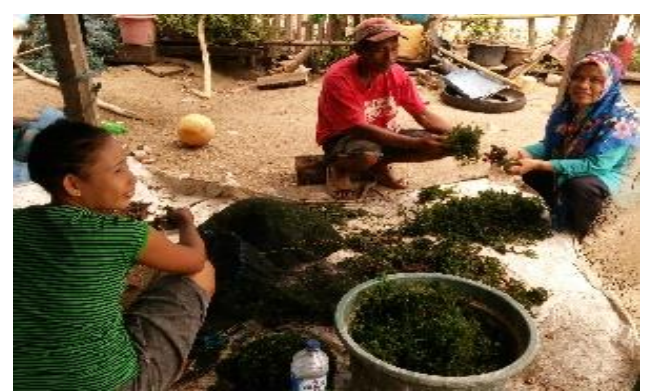

Gambar 7. Proses sortir

\section{B. Bidang Pengolahan}

Adanya pendampingan iptek bagi masyarakat dan penerapan teknologi tepat guna pada kelompok mitra maka, rumput laut yang biasanya dijual langsung secara gelondongan dan murah. Sekarang ini mitra sudah dapat mengolahnya sendiri menjadi produk olahan pangan sebagai usaha home industry yakni produk bakso rumput laut dipadukan denga surimi ikan di Punaga Kabupaten Takalar. Adapun teknik pengolahannya seperti pada Gambar 8, 9 dan 10.
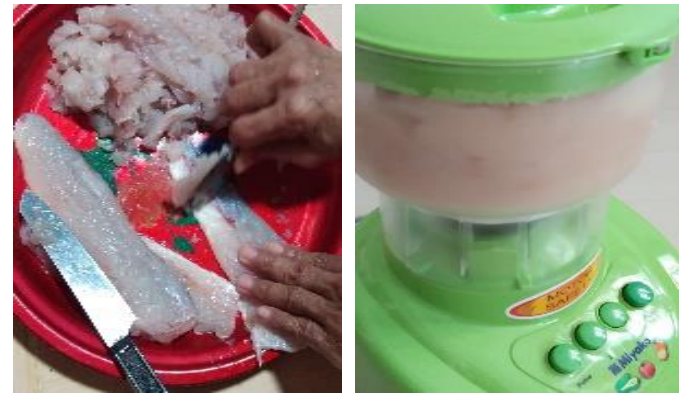

Gambar 8. Proses pengolahan bakso
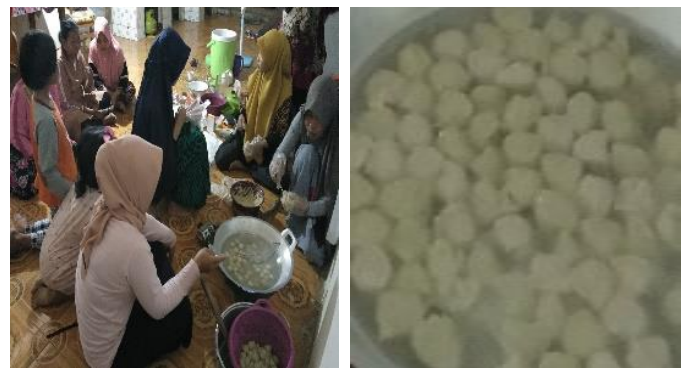

Gambar 9. Produksi bakso

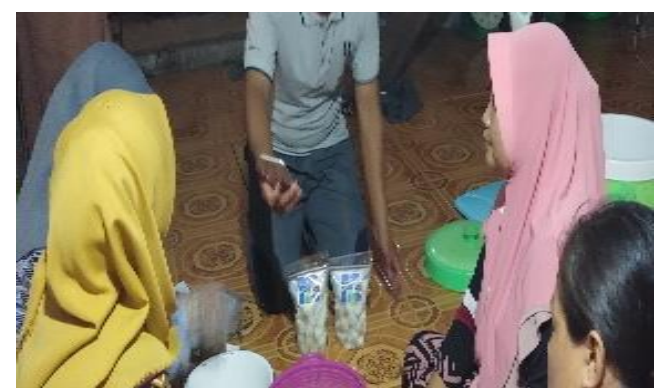

Gambar 10. Pengemasan bakso

\section{KESIMPULAN}

a. Pelatihan dan pendampingan pasca panen rumput laut pada mitra telah dilaksanakan oleh karena itu kelompok mitra, telah memahami proses pengolahan pasca panen rumput laut sehingga dapat menghindari resiko kerusakan dan kerugian.

b. Penerapan teknologi tepat guna dalam proses pengolahan bakso rumput laut serta pengolahan surimi ikan sebagai bahan tambahan berbagai prodak olahan ikan sudah dilaksanakan.

c. Hasil penerapan program kemitraan masyarakat maka pola pikir dan wawasan mitra sudah berubah, dari pola petik jual berkembang menjadi pola petik olah jual. hal tersebut terbukti dengan meningkatnya pengetahuan dan keterampilan mitra, dan selanjutnya berdampak positif pada pendapatan kelompok mitra.

\section{DAFTAR PUSTAKA}

Daniati, T. 2005. Pembuatan bakso ikan cucut dengan bahan tambahan jenis tepung yang berbeda. Tugas akhir. Jurusan Teknologi Jasa dan Produksi Fakultas Teknik Universitas Negeri Semarang. Semarang. 